\title{
APLIKASI PENGOLAH CITRA UNTUK MENENTUKAN JENIS TANAH PADA LAHAN PERTANIAN
}

\author{
Ilham $^{1}$, Pasnur ${ }^{2}$ \\ Teknik Informatika STMIK AKBA ${ }^{1}$, Sistem Informasi STMIK AKBA ${ }^{2}$ \\ Email: ilham@akba.ac.id ${ }^{1}$, pasnur@akba.ac.id ${ }^{2}$
}

\begin{abstract}
ABSTRAK
Penelitian ini bertujuan untuk Membuat dan mengimplementasikan aplikasi pengolahcitrauntukmenentukanjenistanahpadalahanpertaniandengan menggunakan metode Gray Level Co-occurence Matrices diimplementasikan menggunakan bahasa pemrograman Visual Basic 6.Pemilihan lahan pertanian di Indonesia, secara umum, dilakukan sendiri oleh petani tanpa memperhitungkan kesesuaian lahan tersebut dengan tanaman yang akan diaplikasikan. Hal ini dapat berakibat pada berkurangnya hasil panen. Klasifikasi jenis tanah juga dapat dilakukan dengan menganalisis hasil pengukuran dari Cone Penetration Test (CPT). Namun, CPT menggunakan peralatan khusus yang akan sulit diadakan oleh para petani. Selain menggunakan peralatan khusus, terdapat tata cara yang harus ditaati oleh pihak yang akan melakukan CPT. Berdasarkan permasalahan yang telah diuraikan, akan dirancang sebuah aplikasi yang dapat menentukan jenis tanah pada lahan pertanian. Citra tanah pada lahan pertanian akan diolah menggunakan Gray Level Co-occurrence Matrix (GLCM). Dengan GLCM, ekstraksi ciri dapat dilakukan pada citra tanah, sehingga dapat ditentukan jenis tanah dari citra tersebut. Hasil yang diperoleh adalah berupa perancangan aplikasi yang dapat melakukan ekstraksi ciri pada citra tanah menggunakan metode GLCM.
\end{abstract}

Kata Kunci: Klasifikasi jenis tanah, ekstraksi ciri, GLCM.

\section{PENDAHULUAN}

Pertanian merupakan salah satu basis ekonomi kerakyatan di indonesia. Pertanian pula yang menjadi penentu ketahanan, bahkan kedaulatan pangan. Sehingga diperlukan inovasi-inovasi baru dalam peningkatan dalam bidang pertanian khususnya dalam peningkatan kualitas tanah. Karena, tanah merupakan media tempat tumbuh dan berkembangnya akar tanaman. Agar mampu menjalankan peran tersebut, maka tanah harus memiliki kesuburan dan kesehatan yang baik.

Pengklasifikasian kondisi tanah kedalam kelas-kelas tertentu berdasarkan tekstur dan warna sebagian besar masih dilakukan secara manual oleh manusia. Pemilihan lahan secara manual ini tentu menimbulkan permasalahan khususnya pada petani dikarenakan terbatasnya kemampuan manusia. Kemampuan manusia dalam menganalisis lahan pertanian secara visual pada umumnya kurang begitu peka terhadap perubahanperubahan kecil yang terjadi secara bertahap. Salah satu bentuk dari dampak pemilihan lahan secara manual ini yaitu hasil panen yang kurang karena, sebagian dari petani di Jeneponto khususnya di Desa Camba-Camba hanya bergantung pada musim, yaitu musim hujan dan kemarau tanpa mengetahui kandungan yang terdapat pada lahan tersebut.

Untuk mengatasi hal ini maka dibutuhkan teknologi untuk menganalisis suatu tekstur dan warna tanah agar dapat 
diklasifikasikan kedalam kelas-kelas tertentu secara automatis, sehingga mampu mengetahui jenis tanah pada lahan pertanian.

Penelitian sebelumnya yang telah dilakukan, yang membahas karakteristik tanah yang berkembang pada formasi batuan gunung Lompobattang di Kabupaten Jeneponto menghasilkan informasi berupa profil tanah yang diperoleh dari analisis laboratorium [1]. Berdasarkan laporan tersebut, penulis ingin melakukan proses pengembangan yang nantinya akan menghasilkan sebuah sistem pendeteksi kandungan tanah dengan menyatukan sistem pengolahan citra dan hasil laporan profil tanah dengan menggunkan metode gray level cooccurence matrices.

\section{Gray Level Co-Occurence Matrices (GLCM)}

Gray Level Co-occurence Matrices (GLCM) pertama kali diusulkan oleh Haralick pada tahun 1973 dengan 28 fitur untuk menjelaskan pola spasial [2]. GLCM menggunakan perhitungan tekstur pada orde kedua. Pengukuran tekstur pada orde pertama menggunakan perhitungan statistik didasarkan pada nilai piksel citra asli semata, seperti varians, dan tidak memperhatikan hubungan ketetangaan piksel. Pada orde kedua, hubungan antarpasangan dua piksel citra asli diperhitungkan [3]

Matriks ko-okurensi adalah salah satu metode statistik yang dapat digunakan untuk analisis tekstur. Matrik ko-okurensi dibentuk dari suatu citra dengan melihat pada piksel-piksel yang berpasangan yang memiliki intensitas tertentu. Penggunaan metode ini berdasar pada hipotesis bahwa dalam suatu tekstur akan terjadi perulangan konfigurasi atau pasangan aras keabuan. Misal, d didefinisikan sebagai jarak antara dua posisi piksel, yaitu $(\mathrm{x} 1, \mathrm{y} 1)$ dan $(\mathrm{x} 2, \mathrm{y} 2)$ dan $\theta$ didefinisikan sebagai sudut diantara keduanya. Maka matriks ko-okurensi didefinisikan sebagai matriks yang menyatakan distribusi spasial antara dua piksel yang bertetangga yang memiliki intensitas $i$ dan $j$, yang memiliki jarak d diantara keduanya, dan sudut $\theta$ diantara keduanya. Matriks ko-okurensi dinyatakan dengan $P_{d} \theta \quad(i, j)$ Suatu piksel yang bertetangga yang memiliki jarak $d$ diantara keduanya, dapat terletak di delapan arah yang berlainan hal ini ditunjukkan pada gambar 1 .

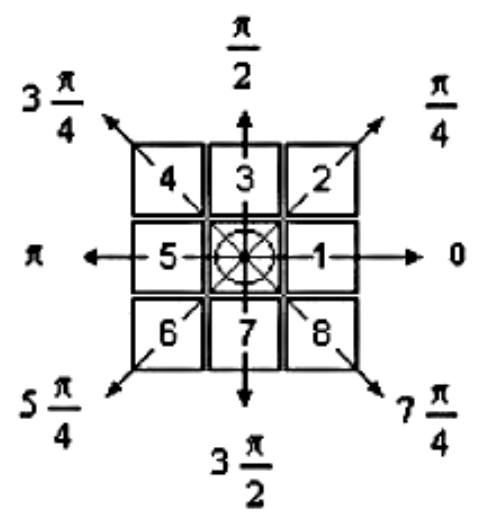

Gambar 1. Piksel bertetangga dalam delapan arah

Dalam matriks ko-okurensi, terdapat sebelas cirri tekstur yang dapat diperoleh dari suatu citra yang digunakan sebagai pembeda antara citra dengan kelas tertentu, dengan kelas lainnya [4]. Ciri-ciri tersebut adalah :

1. Energi (Energy)

$$
\mathrm{f}_{1}=\sum_{\mathrm{i}} \sum_{\mathrm{j}} \mathrm{p}_{\mathrm{d}}^{2}(\mathrm{i}, \mathrm{j})
$$


2. Entropi (Entropy)

$$
\mathrm{f}_{2}=-\sum_{\mathrm{i}} \sum_{\mathrm{j}} \mathrm{p}_{\mathrm{d}}(\mathrm{i}, \mathrm{j}) \log \left(\mathrm{p}_{\mathrm{d}}(\mathrm{i}, \mathrm{j})\right)
$$

3. Kontras (Contrast)

$$
f_{3}=\sum_{i} \sum_{j}(i-j)^{2} p_{d}(i, j)
$$

4. Homogenitas (Homogeneity)

$$
f_{4}=\sum_{i} \sum_{j} \frac{p_{d}(i, j)}{1+|i-j|}
$$

5. Korelasi (Correlation)

$$
\mathrm{f}_{5}=\sum_{\mathrm{i}} \sum_{\mathrm{j}} \frac{\mathrm{ijp}_{\mathrm{d}}(\mathrm{i}, \mathrm{j})-\mu_{\mathrm{x}} \mu_{\mathrm{y}}}{\sigma_{\mathrm{x}} \sigma_{\mathrm{y}}}
$$

6. Momentum Selisih Invers (Inverse Difference Momentum)

$$
\mathrm{f}_{6}=\sum_{\mathrm{i}} \sum_{\mathrm{j}} \frac{1}{1+(\mathrm{i}-\mathrm{j})^{2}} \mathrm{p}_{\mathrm{d}}(\mathrm{i}, \mathrm{j})
$$

7. Rata-rata Jumlah (Sum Average)

$$
\mathrm{f}_{7}=\sum_{\mathrm{k}=2}^{2 \mathrm{~N}_{\mathrm{g}}} \mathrm{k} \sum_{\substack{\mathrm{i}, \mathrm{j} \\ \mathrm{i}+\mathrm{j}=\mathrm{k}}} \mathrm{p}_{\mathrm{d}}(\mathrm{i}, \mathrm{j})
$$

8. EntropiJumlah (Sum Entropy)

$$
\mathrm{f}_{8}=-\sum_{\mathrm{k}=2}^{2 \mathrm{Ng}} \sum_{\mathrm{i}, \mathrm{j}} \mathrm{p}_{\mathrm{d}}(\mathrm{i}, \mathrm{j}) \log \left(\mathrm{p}_{\mathrm{d}}(\mathrm{i}, \mathrm{j})\right)
$$

9. VariansJumlah (Sum Variance)

$$
f_{9}=\sum_{k=2}^{2 N g} \sum_{\substack{i, j \\ i+j=k}}\left(k-f_{7}\right)^{2} p_{d}(i, j)
$$

10. VariansSelisih (Difference Variance)

$$
\mathrm{f}_{10}=\operatorname{var}\left\{\sum_{\substack{\mathrm{i}, \mathrm{j} \\|\mathrm{i}-\mathrm{j}|=\mathrm{k}}} \mathrm{p}_{\mathrm{d}}(\mathrm{i}, \mathrm{j})\right\}_{\mathrm{k}=0, \ldots, \mathrm{Ng}-1}
$$

11. EntropiSelisih (Difference Entropy)

$$
\mathrm{f}_{11}=-\sum_{\mathrm{k}=0}^{\mathrm{Ng}-1} \sum_{\substack{\mathrm{i}, \mathrm{j} \\|\mathrm{i}-\mathrm{j}|=\mathrm{k}}} \mathrm{p}_{\mathrm{d}}(\mathrm{i}, \mathrm{j}) \log \left(\mathrm{p}_{\mathrm{d}}(\mathrm{i}, \mathrm{j})\right)
$$

\section{Tekstur}

Tekstur adalah sebagai hubungan mutual antara nilai intensitas piksel-piksel yang bertetangga yang berulang disuatu area yang lebih luas daripada jarak hubungan tersebut [2].

Secara umum tekstur mengacu pada pengulangan elemen-elemen tekstur dasar yang disebut primitive atau teksel (texture element-texel).Syarat-syarat terbentuknya suatu tekstur antara lain :

1. Adanya pola-pola primitif yang terdiri dari satu piksel atau lebih. Bentukbentuk pola primitive ini dapat berupa titik, garis lurus, garis lengkung, luasan, dan lain-lain yang merupakan elemen dasar dari sebuah tekstur.

2. Pola-pola primitive tersebut muncul berulang-ulang dengan interval dan arah tertentu sehingga dapat diprediksi atau ditemukan karakteristik pengulangannya.

Suatu citra memberikan interpretasi tekstur yang berbeda apabila dilihat dengan jarak dan sudut yang berbeda. Manusia memandang tekstur berdasarkan 
deskripsi yang bersifat acak, seperti halus, kasar, teratur, tidak teratur, dan sebagainya. Hal ini merupakan deskripsi yang tidak tepat dan non-kuantitatif, sehingga diperlukan adanya suatu deskripsi yang kuantitatif (matematis) untuk memudahkan analisis.

\section{K-Nearest Neighbor}

Metode

k-nearest

neighbor

adalahsebuahmetodeuntukmelakukanklasif

ikasiterhadapobjek, berdasarkan data pembelajaran yang jaraknya dekat dengan objek tersebut, sesuai jumlah tetangga terdekatnya atau nilai k. Dekat atau jauhnya tetangga tersebut biasanya dihitung berdasarkan jarak Euclidean dengan persamaan sebagai berikut:

$$
d(x-y)=\sqrt{\sum_{j=1}^{n}\left(x_{j}-y_{j}\right)^{2}}
$$

\section{Dengan}

$\mathrm{d}$ :jarak data ujike data pembelajaran $\mathrm{x} j$ : data ujike-j, dengan $\mathrm{j}=1,2, \ldots, \mathrm{n}$ $y j$ : data belajarke- $\mathrm{j}$, dengan $\mathrm{j}=1,2, ., \mathrm{n}$

Klasifikasi k-NN dilakukan dengan mencari $\mathrm{k}$ buah tetangga terdekat dari data uji dan memilih kelas dengan anggota terbanyak.

\section{Temu Kembali Citra}

\section{Temu kembali citra (image retrieval) merupakan proses untuk mendapatkan sejumlah citra berdasarkan masukan satu citra. Istilah yang lebih spesifik lagi adalah content based image retrieval (CBIR) atau temu kembali citra berdasarkan isinya. Istilah tersebut dikemukakan pertama kali oleh Kato pada tahun 1992 [5].}

\section{Tanah}

Tanah merupakan suatu sistem lapisan kerak bumi yang tidak padu dengan ketebalan beragam berbeda dengan bahanbahan dibawahnya, yang juga tidak baku dalam hal warna, bangunan fisik, struktur, susunan kimiawi, sifat biologi, proses kimia ataupun reaksi-reaksi.

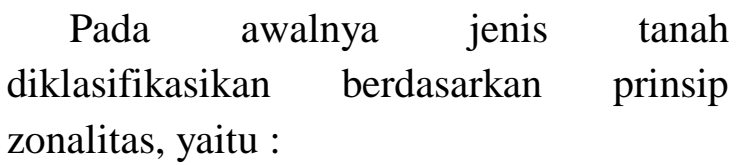

a. Tanah Zonal, yakni tanah dengan faktor pembentuk tanah berupa iklim dan vegetasi.

b. Tanah Intrazonal, yakni tanah dengan faktor pembentuk tanah berupa faktor lokal terutama bahan induk dan relief.

c. Tanah Azonal, yakni tanah yang belum menunjukkan perkembangan profil dan dianggap sebagai awal proses pembentukan tanah.

\section{METODE PENELITIAN}

Dari jenis tanah Kabupaten Jeneponto terdapat 6 (enam) golongan jenis tanah yaitu, Alluvial, Gromosal, Mediteren, Lotosal, Andosil, dan Regional. Desa Camba-camba Kec Batang merupakan salah satu tempat di Jeneponto yang memiliki dua jenis lahan.

Pertama lahan yang lokasinya dekat dengan sungai dapat melakukan proses penanaman padi secara berkesinambungan baik pada musim kemarau maupun pada musim hujan. Dan yang kedua lahan atau daerah persawahan yang lokasinya jauh dari sungai hanya akan menanam padi pada musim hujan dan ketika musim kemarau petani menganti tanaman padi dengan kacang-kangan atau umbi-umbian. Jenis tanah yang terdapat di Desa CambaCamba Kec Batang Kab Jeneponto yaitu: 


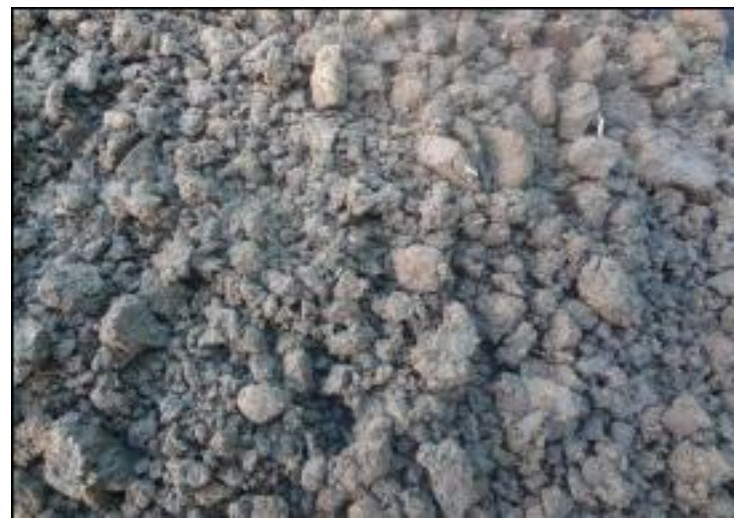

Gambar 2. Tanah Alfisol

Tanah alfisol yaitu tanah yang menyebar didaerah yang beriklim sedang sampai daerah tropis (lembab).

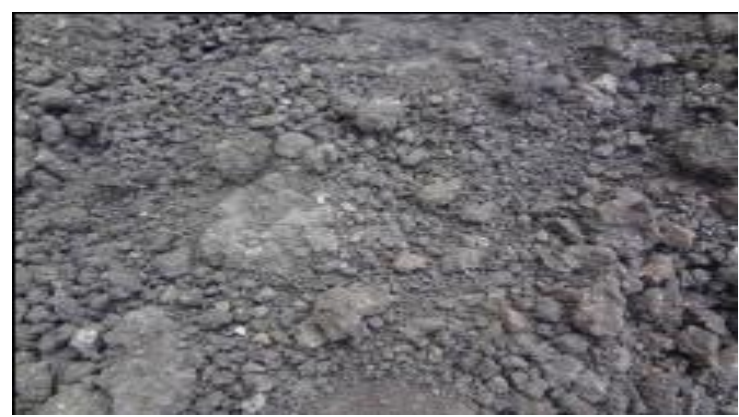

Gambar 3. Inceptisol

Tanah Inceptisol termasuk kedalam jenis tanah Alluvial. Banyak terdapat di lembah-lembah atau jalur aliran sungai dan dataran pantai.

\section{MetodePerancangan}

Tahapan-tahapan dalam penelitian ini, secara garis besar ditunjukkan pada Gambar 4.

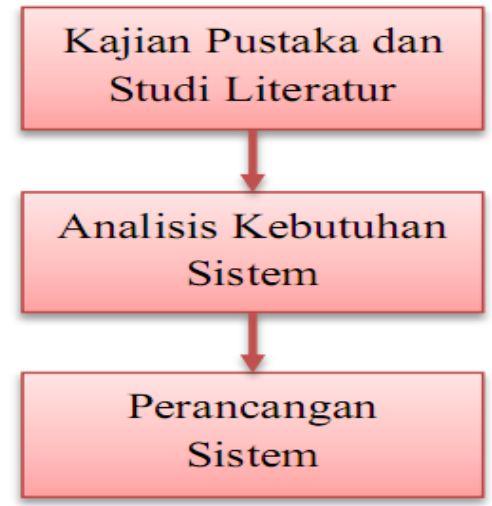

Gambar 4. Tahapan penelitian
Tahap awal yang dilakukan adalah mengkaji pustaka dan studi literatur terhadap beberapa referensi yang relevan dengan topik penelitian. Adapun referensi yang dirujuk dalam penelitian ini adalah beberapa penelitian yang berkaitan dengan topik penelitian, pengelompokan jenis tanah, teknik pengolahan citra yang dibutuhkan untuk melakukan analisis, dan teknik pemrograman yang dibutuhkan dalam menerapkan hasil analisis pengolahan citra pada aplikasi yang akan dibuat.

Setelah itu, dibuat analisis kebutuhan sistem. Pada tahapan ini, akan dilakukan analisis terhadap user, apa yang dibutuhkan oleh user, apa saja yang dapat dilakukan oleh user. Selain itu, dalam tahapan ini juga akan dianalisis pula halhal yang dibutuhkan dalam melakukan analisis terhadap citra sehingga dapat diperoleh hasil yang diinginkan. Dengan demikian, perancangan yang akan dilakukan selanjutnya dapat relevan.

Tahap akhir penelitian ini adalah perancangan sistem. Tahapan perancangan aplikasi merupakan lanjutan dari tahapan analisis kebutuhan sistem. Perancangan aplikasi akan sepenuhnya mengacu pada analisis kebutuhan sistem. Adapun prinsip kerja aplikasi yang akan dirancang, ditunjukkan pada Gambar 5.

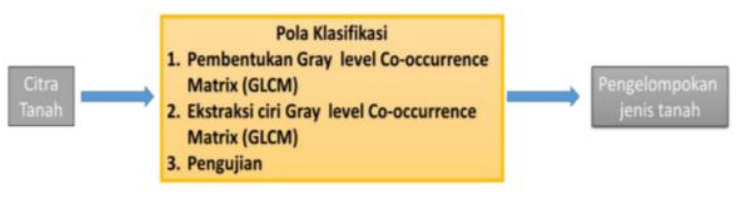

Gambar 5. Prinsipkerjaaplikasi

\section{Flowchart Sistem}

Flowchart sistem merupakan cara penyajian dari suatu algoritma atau proses 
yang menampilkan langkah-langkah yang disimbolkan dalam bentuk kotak, beserta urutannya dengan menghubungkan masing-masing langkah tersebut menggunakan tanda panah.

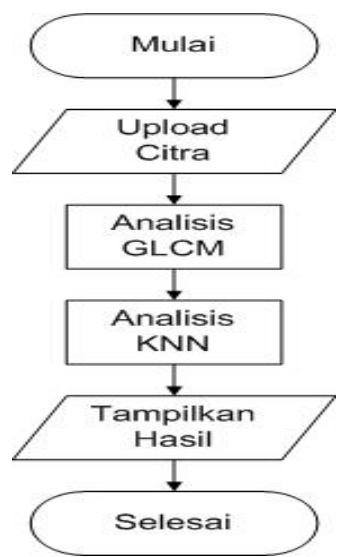

Gambar 6. Flowchart system

a. Diagram Konteks

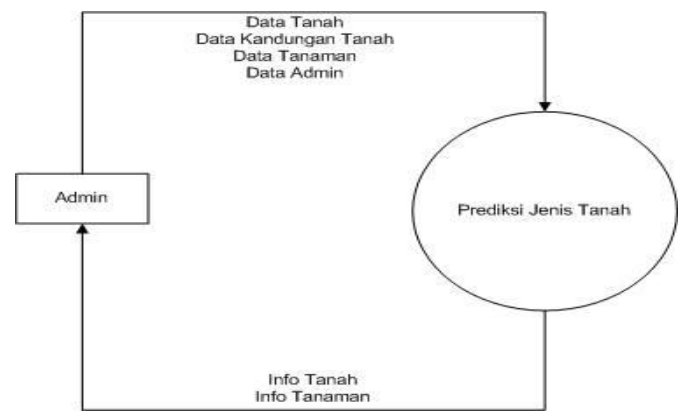

Gambar 7. Diagram Konteks

b. DFD Level 0

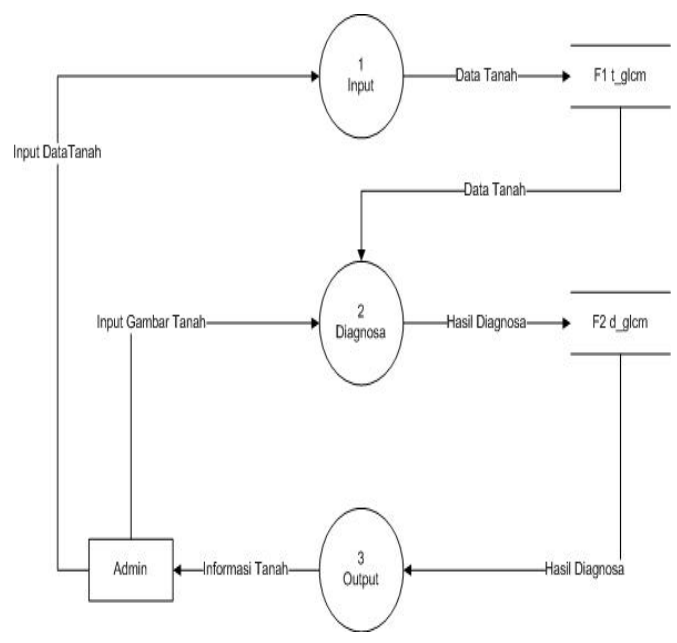

Gambar 8. DFD Level 0

\section{Hasil Perancangan}

Pengujian aplikasi ini menggunakan metode pengujian Black Box. Pengujian Black Box berfokus pada persyaratan atau fungsional perangkat lunak yang dibuat. Rencana pengujian adalah pengujian terhadap fungsi-fungsi yang ada di dalam sistem, apakah fungsi tersebut berfungsi sesuai yang duharapkan atau tidak.

Berdasarkan hasil pengujian maka dapat disumpulkan tampilan aplikasi dengan nilai rata-rata $88 \%$, membantu pengguna dalam mendeteksi jenis tanah dengan nilai rata-rata $92 \%$, aplikasi sudah sudah memenuhi memperoleh informasi dengan nilai rata-rata $88 \%$, kemudahan dalam menggunakan aplikasi dengan nilai rata-rata 88\%, kelengkapan fitur yang disajikan dengan nilai rata-rata $88 \%$.

Dari hasil pengujian diatas diperoleh nilai rata-rata diperoleh nilai rata-rata $96,6 \%$, ini dapat disimpulkan bahwa secara umum aplikasi pengolah citra untuk menentukan jenis tanah pada lahan pertanianDalam Mendeteksi Jenis Tanah ini bisa bermanfaat dan memenuhi kebutuhan para petani dan penyuluh pertanian.

Adapun tampilan aplikasi pengolah citra untuk menentukan jenis tanah pada lahan pertanian sebagai berikut :

a. Tampilan Utama

Tampilan utama merukan tampilan awal pada saat aplikasi dijalankan.

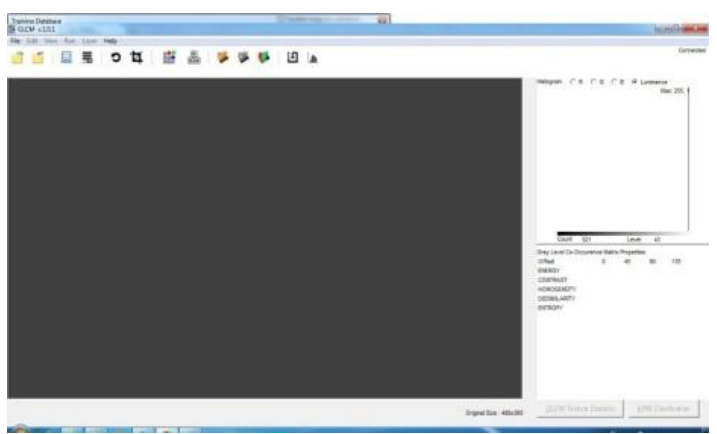

Gambar 9. Halaman utama 
b. Tampilan Load File

Pada aplikasi ini Load file digunakan untuk meng upload file gambar kedalam aplikasi sebelum dianalisis. Seperti terlihat pada gambar 10. yaitu:

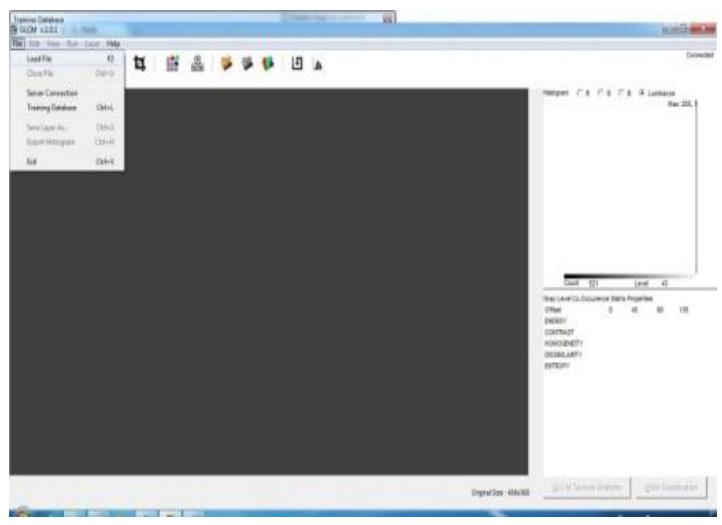

Gambar 10. Load File

c. Proses upload File

Pada proses ini disediakan beberapa gambar sebgai semple yang digunankan dalam penelitian ini. Gambar dibawah sudah didatabasekan yang nantinya akan dianalisis oleh sistem, spserti terlihat pada gambar 11 . yaitu:

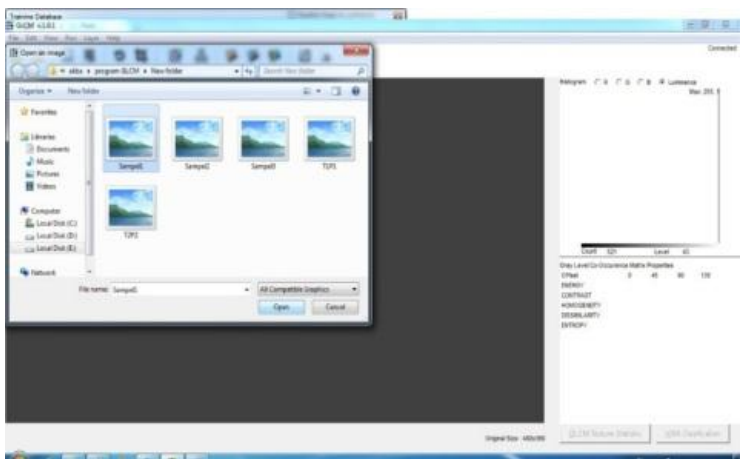

Gambar 11. Proses Upload gambar

d. Tampilan Proses Analisis GLCM

Setalah proses upload gambar selesai maka Button tombol GLCM texture statistic dan tombol KNN Clasification sudah aktif seperti terlihat gambar 12. yaitu:

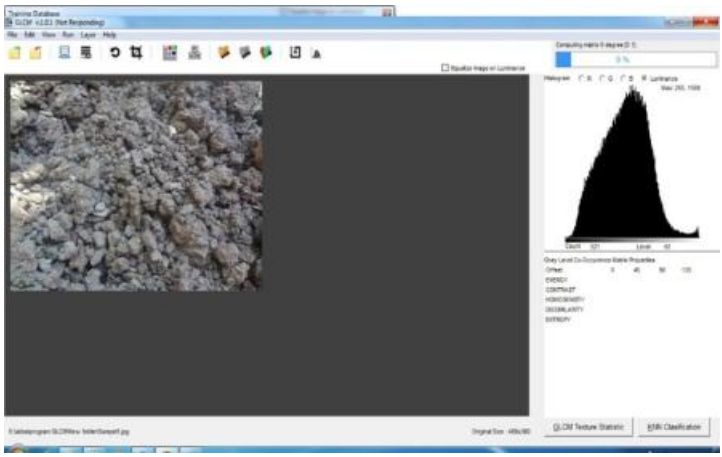

Gambar 12. Proses Analisis GLCM

e. Tampilan Setelah Proses GLCM Selesai

Setelah proses GLCm selesai maka akan muncul statistik dan tabel hasil proses GLCM, seperti terlihat pada gambar 13, yaitu:

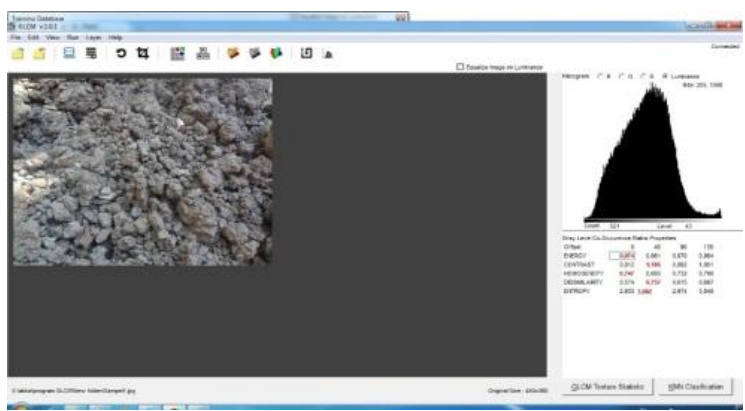

Gambar 13. Setelah Proses GLCM

f. Tampilan Hasil dari KNN

Berikut merupakan hasil analisis $\mathrm{KNN}$, proses KNN dilakukan setelah melakukan proses GLCN, seperti terlihat pada gambar 14 yaitu:

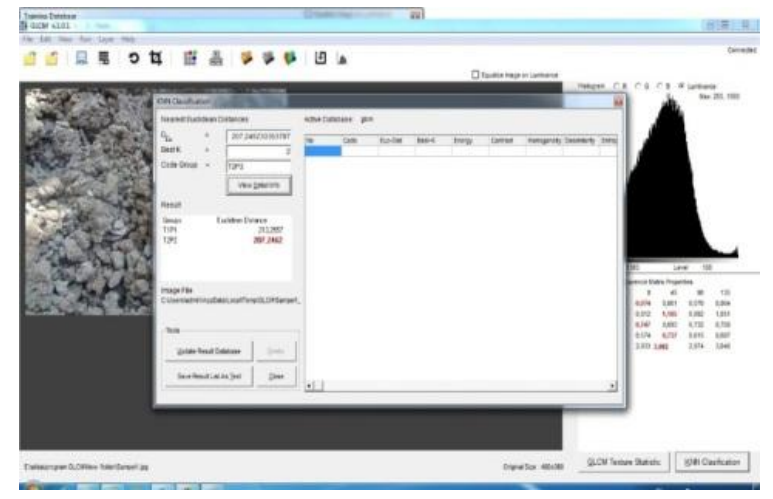

Gambar 14. Hasil dari KNN 
g. Report

Pada report dalam aplikasi GLCM ini yang digunakan untuk analisis tanah terdiri dari beberapa yaitu Kode tanah, Jenis Tanah, Bahan Induk, Lokasi semple, koordinat, tinggi permukaan, topografi, vegetasi, drainase, kedalaman efektif dan Klassifikasi, seperti terlihat pada gambar 15 yaitu :

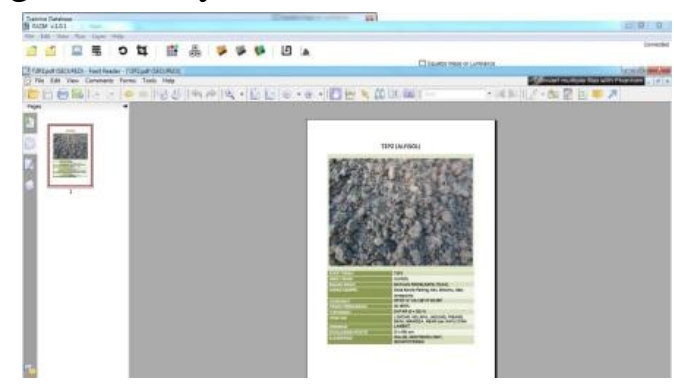

Gambar 15. Report

\section{PENUTUP}

Sesuai dengan pembahasan mengenai aplikasi pengolah citra untuk menentukan jenis tanah pada lahan pertanian, maka dapat disimpulkan sebagai berikut.

\section{Aplikasi}

pengolahcitrauntukmenentukanjeni stanahpadalahanpertaniandenganm enggunakanGray Level Cooccurence Matrices dirancang untuk mendeteksi jenis tanah pada lahan pertaniandapatmengklasifikasikanj enistanahpertanian dengan menghasilkan informasi berupa jenis tanah, tanaman yang dapat atau cocok ditanami.

2. Dari hasil pengujian diperoleh nilai rata-rata diperoleh nilai rata-rata $96,6 \%$, ini dapat disimpulkan bahwa secara umum aplikasi pengolah citra untuk menentukan jenis tanah pada lahan
pertanianDalam Mendeteksi Jenis Tanah ini bisa bermanfaat dan memenuhi kebutuhan para petanidanpenyuluhpertanian.

\section{Daftar Pustaka}

[1]. Ratih Fatirah.2011,.Karakteristik Tanah Yang Berkembang Pada Formasi Batuan Gunung Lompobattang Di Kabupaten Jeneponto. Universitas Hasanuddin

[2]. Kadir, Abdul dan Adhi.2013. Pengolahan Citra. Andi Yogyakarta

[3]. Hall-Beyer, Mryka, 2008 The GLCM Tutorial Home Page, [Online], URL: http://www.fp.ucalgary.ca/mhallbey/th e_glcm.htm,

[4]. YudhistiraGanis K, Imam Santoso, R. Rizal Isnanto,Klasifikasi Citra DenganMatriksKo-Okurensi Aras Keabuan(Gray Level Co-Occurrence Matrix-Glcm)Pada Lima KelasBijiBijian. Diaksespadatanggal 15 november 2018 [Online], URL: https://www.academia.edu/30093210/ KLASIFIKASI_CITRA_DENGAN_ MATRIKS_KO-

OKURENSI_ARAS_KEABUAN_Gr ay_Level_Co-occurrence_MatrixGLCM_PADA_LIMA_KELAS_BIJIBIJIAN

[5]. Zhang, R. and Zhang, Z., (2002), A Clustering Based Approach to Efficient Image Retrieval, Proceedings of the 14th IEEE International Conference on Tools with Artificial Intelligence, pp. 339. 